(2019), 1 (2): 67-71

\title{
STUDENTS’ MOTIVATIONAL FACTORS IN WRITING ESSAY
}

\author{
Hernina Dewi Lestari \\ IKIP Budi Utomo \\ herninadewilestari@gmail.com
}

\begin{abstract}
This study aims at discovering the possible motivational factors affecting English Department students in writing essay. Employing descriptive qualitative mode of research, the researcher tried to figure out the concerning factors especially the motivational areas which possibly became the major support and/or hindrance for the students to write essay. To meticulously note down the result, the researcher made use of unstructured interview as the method of collecting the data. The result found teacher's overall performance, peers' performance, parent's involvement, and classroom ambience as the dominant motivational factors affecting students' performance in writing essay. Future researchers are suggested to study the more specific areas of motivational factors affecting students in writing essay to get better and deeper understanding.
\end{abstract}

Keywords: motivational factors, writing, essay

CPendidikan Bahasa Inggris FPISH IKIP BU Malang

\section{Introduction}

Writing receives a major vote as a relatively difficult skill to acquire. Hedge in Alfaki (2015) suggested that, compared to speech, effective writing requires a number of things: a high degree of organization in the development of ideas and information; a high degree of accuracy so that there is no ambiguity of meaning; the use of complex grammatical devices for focus and emphasis; and a careful choice of vocabulary, grammatical patterns, and sentence structures to create a style which is appropriate to the subject matter and the eventual readers. In learning English as a foreign language, the pressure is doubled for students to acquire writing skill.

Students' performance in acquiring writing skill is highly affected by various factors. One of the most affecting factors in learning how to write especially in a foreign language is motivational factors. Of course, there are other factors which also greatly affect the students' performance. However, this study focuses on discovering the possible motivational factors affecting the students in writing essay.

As a matter of fact, many experts confirmed that motivation is said to be one major determinant which affect students' achievement. According to Harmer, 2007; Reid, 2007), motivation is regarded as a primary factor for one's successful learning. In addition, Kimura, Nakata, \& Okumura, 2000) suggested that most language teachers agree that motivation is a determining factor for the success of language learning.

Why it should be about writing essay? English Department students in IKIP Budi Utomo, who became the subject of this study, have to attend multiple writing classes in order to acquire certain level in writing skill. One of the area that the students should master is essay writing. Moreover, those who attended the more advanced level of writing course should deal with essay writing which, then, became quite a nightmare for the students. It is due to essay writing is pronounced to require high level of thinking and expressing the idea processes. Empirical studies also discover that writing essays is not an 
easy task to proceed and cannot be mastered without sufficient formal practices due to being a complex cognitive activity which requires five attention levels; they are thematic, paragraph, sentence, grammar, and lexical (Lavelle, Smith, \& O’Ryan, 2002).

Therefore, based on the described research backdrop, this research focused on finding the motivational factors affecting the students in writing essay. The results of the study are expected to be able to contribute to the theoretical framework about motivational factors in essay writing. Since the appearance of the research limitation in describing the findings on motivational factors which may be only cover the surface of the research area, further research is required to complete the deeper discussion.

\section{Research Method}

This research employed descriptive qualitative design as description of motivational factors affecting students' performance in writing essay was used to answer the research problem. The study was conducted in IKIP Budi Utomo as one of the private higher institution in Malang city which is located at Jalan Citandui No, 46, Malang, East Java. The whole process of the research was covered in the odd semester in academic year of 2018/2019 when the Scientific Writing course was provided. In the course, the students actively practiced on writing essay. The subject of this study was the English Department students Class 2016 B who took Scientific Writing course.

The researcher initiated the procedure of this research by conducting interview to the subject of the study regarding the motivational factors which possibly become the inspiration and/or hindrance towards the students' achievement in writing essay. The interview was set to be unstructured interview as the researcher expected to discover unlimited findings on motivational factors affecting the students in essay writing. After the interview was done, the researcher analyzed the data by categorizing the appeared motivational factors obtained from the interview with the students. Then, the researcher found the percentage of the students who answered certain category to find the dominant factors to make a conclusion.

\section{Findings and Discussion}

The findings from the study showed that there were several dominant aspects which can be described as the motivational factors affecting the students' performance in writing essay; they are teacher's performance, peer's performance, parent's involvement, and classroom ambience.

The result presented the data of $45 \%$ of the students agreed to mention teacher's performance to be one important motivational factor which determine whether the students were motivated to do better or worse. The students mentioned the clarity of the teacher's instruction, constructive yet challenging feedbacks, and teacher's consideration in setting the achievement standard as the most major aspects regarding teacher's performance affecting the students' achievement.

Regarding the first aspect of this research finding, it can be concluded that most likely the teacher approached the teaching and learning process through goal-related theory. Conti (2015) described that goal-related theory is approved to be one of the motivational theories which contribute to the implications for the classroom. In the theory, three aspects which become the main focus was the aspect of clear, challenging, and achievable. Clear aspect may be interpreted as the clear 
instruction from the teacher so that the students know what to do and what not to do. The second aspect is challenging where the teacher should provide activity or, in this case feedback for their writing, so that the students get the stimulation to experience a more meaning learning process. The third aspect is achievable which can imply the consideration the teacher made to set the learning objective based on the students' situation so that the students did not need to be afraid of failing.

The second aspect found from conducting this study was peer's performance. The data showed that 55\% of the students voted peer's performance as one top motivational factor affecting their learning outcome. As a matter of fact, inspiring classmates may be the positive motivation for students' achievement. On the other hand, overdominant students became the obstacle for the students to develop their skill optimally. Moreover, the subject of the study showed the gesture of two different groups of students which indicated students' achievement. Those with high level of performance stayed as friends with those who have similar performance and vice versa. Related to this finding, Laninga-Wijnen et.al. (2018) added the findings of their study regarding friendship influence on students' achievement. They pronounced that adolescents formed friendships with similarly achieving peers in classroom with high performance goal popularity norms. Contradictorily, students in higher level of education remained friends with similarly achieving peers in classrooms with low performance goal popularity norms but not in classrooms with high performance goal popularity norms. They also added that friendship influence on achievement occurred in classrooms with high mastery goal popularity norms, but not in classrooms with low mastery goal popularity norms.
The findings show that peer's performance do affect other students' performance, in this case, no matter what age they were in. In summary, adolescents and adult learners shared similar characteristic on this matter.

The third aspect affecting students' performance in writing essay was parent's involvement in supporting the students' learning process. The data collected presented that $37 \%$ of the students declared parent's support to be significant in determining students' writing achievement. The students highlighted that parent's involvement should be in the right amount to positively support the students' academic improvement. The less or over involvement would not provide the expected ideal outcome towards the students' performance, in this case in essay writing. The findings from a research conducted by Topor et.al. (2010) claimed that the increased parent involvement, defined as the teacher's perception of the positive attitude parents have toward their child's education, teacher, and school, was significantly related to increased academic performance, measured by both a standardized achievement test and teacher ratings of the child's classroom academic performance. Even their research justified that parent involvement was significantly related to academic performance above and beyond the impact of the child's intelligence (IQ).

The last dominant motivational factors affecting students' achievement on essay writing found in this study was classroom ambience of atmosphere. The data collected presented that $70 \%$ of the students agreed that classroom atmosphere was included as the major factor affecting students' writing performance. The students described sufficient facilities in the classroom, assignment management (individual, 
group, class project), and seating arrangement were mentioned to be the most crucial things in classroom management to support the teaching and learning process which will affect the students' achievement. Hannah (2013) agreed that classroom environment plays a crucial role in keeping students engaged and allowing them to be successful within the classroom.

The whole findings of the collected data can be simplified in the following Table 1.

Tabel 1. Motivational Factors Affecting Students' Performance in Writing Essay

\begin{tabular}{ccc}
\hline No. & Motivational Factors & $\begin{array}{c}\text { Percentage } \\
\text { (\%) }\end{array}$ \\
\hline 1 & Teacher's & 45 \\
2 & performance & 55 \\
3 & Peer's performance & 37 \\
4 & Parent's involvement & 70 \\
\hline
\end{tabular}

\section{Conclusion}

From the whole description of the background to the findings and the discussion of this study, it can be concluded that the most dominant motivational factors in affecting students' performance in writing essay included teacher's performance, peer's performance, parent's involvement, and classroom ambience.

It is significant to consider those 4 motivational factors as the main aspects to adjust to the characteristics of the students. Therefore, the teacher should be able to manage balancing those motivational factors so that the teaching and learning process was conducted positively to support students' performance, in this case in essay writing.

For future researcher, this study was limited to the general discussion of motivational factors affecting students' performance in writing essay. So, it is expected to conduct further research which focuses on examining each of the motivational aspects in more detailed point of view.

\section{References}

Alfaki, Ibrahim Mohamed. (2015). University Students' English Writing Problems: Diagnosis and Remedy. International Journal of English Language Teaching, 3 (3), 40-52.

Conti, Gianfranco. (2015). Eight motivational theories and their implications for the classroom. Retrieved on $5^{\text {th }}$ January, 2019 from https://gianfrancoconti.wordpress.c om/2015/07/27/eight-motivationaltheories-and-their-implications-forthe-foreign-language-classroom/.

Hannah, R. (2013). The Effect of Classroom Environment on Student Learning. Honors Theses. Paper 2375.

Harmer, J. (2007). The practice of English language teaching. Essex: Pearson Education Limited.

Kimura, Y., Nakata, Y., \& Okumura, T. (2002). Language learning motivation of EFL learners in Japan-A cross sectional analysis of various learning milieus, $J A L T$ Journal, 47-65.

Laninga-Wijnen, L., Harakeh, Z., Ryan, A.M., Shin, H., \& Vollebergh, W. A.M. (2018). The Moderating Role of Popular Peers' Achievement Goals in $5^{\text {th }}$ - and $6^{\text {th }}$ - Graders' Achievement-Related Friendships: A Social Network Analysis. Journal of Educational Psychology, 110 (2), 289-307.

Lavelle, E., Smith, J., \& O’Ryan, L. (2002). The Writing Approaches of Secondary Students. The British Journal of Educational Psychology, 72, 399-418. http://dx.doi.org/10.1348/0007099 02320634564. 
Reid, G. (2007). Motivating learners in the classroom: ideas and strategies. London: Paul Champman Publishing.

Topor, D.R., Keane, S.P., Shelton, T.L., and Calkins, S.D. (2010). Parent involvement and student academic performance: A multiple mediational analysis. J Prev Interv Community, 38 (3), 183-197. 